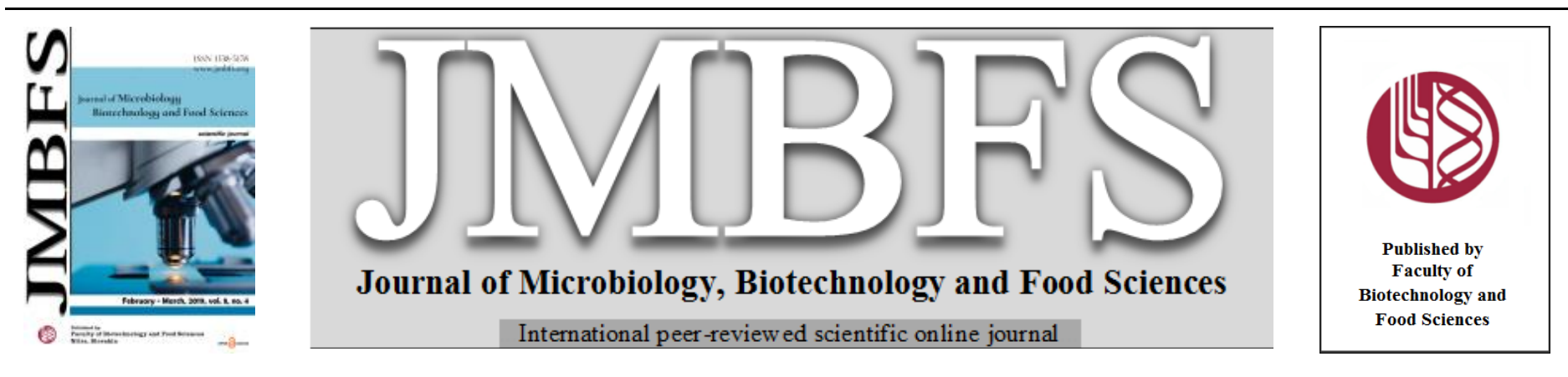

\title{
THE INFLUENCE OF VARIETY ON THE CONTENT OF TOTAL POLYPHENOLS AND ANTIOXIDANT ACTIVITY IN LEEK (ALLIUM PORRUM L.)
}

\author{
Ján Kovarovič*l, Judita Bystrickál ${ }^{1}$,Marianna Micová, ${ }^{1}$ Luboš Harangozo ${ }^{1}$, Juraj Miššì ${ }^{2}$, Alžbeta Hegedüsová ${ }^{3}$
}

Address(es): Ing. Ján Kovarovič,

${ }^{1}$ Slovak University of Agriculture in Nitra, Faculty of Biotechnology and Food Sciences, Department of Chemistry, Tr. A. Hlinku 2, 94976 Nitra, Slovakia.

${ }^{2}$ Slovak University of Agriculture in Nitra, Faculty of Biotechnology and Food Sciences, Department of Biochemistry and Biotechnology, Tr. A. Hlinku 2, 94976 Nitra, Slovakia.

${ }^{3}$ Slovak University of Agriculture in Nitra, Faculty of Horticulture and Landscape Engineering, Department of Vegetable Production , Tr. A. Hlinku 2, 94976 Nitra, Slovakia.

*Corresponding author: xkovarovic@is.uniag.sk

doi: 10.15414/jmbfs.2019.8.4.1072-1075

\section{ARTICLE INFO}

Received 9. 10. 2018

Revised 15. 11. 2018

Accepted 15. 11. 2018

Published 1. 2. 2019

Regular article

open $\bigodot_{\text {ACCESS }}$

\begin{abstract}
Leek (Allium porrum L.) is a member of the Allium genus. It is known for its specific taste and aroma. Leek is used in gastronomy and modern food technologies. It is also important to note that bioactive substances of leek are very little explored. Compared to onion and garlic, little attention is paid to the leek. The samples of plant material were collected from the area of Zohor (Slovakia). The aim of this study was to analyse the content of total polyphenols (TPC) and the value antioxidant activity (AOA) in selected cultivars of leek. The samples of leek were homogenized and a methanolic extract was prepared. These extracts were used for analyses. Total polyphenol content in the samples ranged from 504.22 $\pm 48.28 \mathrm{mg} \mathrm{GAE} . \mathrm{kg}^{-1} \mathrm{DW}$ to $4767.71 \pm 80.55 \mathrm{mg} \mathrm{GAE} . \mathrm{kg}^{-1} \mathrm{DW}$. The values of antioxidant activity were from $4.30 \pm 1.02$ to $47.40 \pm 0.49 \%$ inhibition.
\end{abstract}

Keywords: leek (Allium porrum L.), polyphenols, antioxidant activity, variety

\section{INTRODUCTION}

Vegetable and fruit, being rich in phenolic compounds, carotenoids, glucosinolates, vitamin $\mathrm{C}$ and tocopherols, are plentiful in bioactive compounds. These bioactive compounds have high antioxidant capacity and are important for preventing oxidative stress and chronic diseases (Barba et al., 2017). Consuming sufficient quantities of fruits and vegetables has been identified as a key route to reducing global risk factors for disease (Connell et al., 2018). Vegetable and fruit intake may be associated with reduced deoxyribonucleic acid (DNA) oxidation, cell damage, and low-grade inflammation, as well as increasing the activity of detoxification enzymes (Perez-Cornago et al., 2017).

The Allium genus is characterized by the content of bioactive components: flavonoids, polysaccharides and glucosinolates, as well as numerous organosulfur compounds. Epidemiological and laboratory studies suggest that Allium vegetables have tumor-inhibitory properties. Their consumption reduces risk of prostate cancer, colorectal cancer, stomach cancer and breast cancer (Kratchanova et al., 2010). Allium species including onion (Allium cepa L.), garlic (Allium sativum L.), chives (Allium schoenoprasum L.), leek (Alium porrum L.) and wild garlic (Allium ursinum L.), extensively used for food flavoring, have been recognised as rich sources of secondary metabolites, such as polyphenolic compounds, including phenolic acids (and their derivatives), flavonoids (flavan, flavanone, flavones, flavonol, dihydroflavonol, flavan-3-ol, flavan-4-ol and flavan-3,4-diol) and flavonoid polymers (proanthocyanidins or condensed tannins) (Bernaert et al., 2013). Koca and Tasci (2015) revealed that leek was especially rich in potassium, iron, selenium and it's important source of nutritive elements. Leek (Allium porrum L.) is a bulbous perennial plant with the bulb and the pseudostem formed by the overlapping leaves (Adão et al., 2011). García-Herrera et al. (2014) published that, it has a milder and more delicate flavor than onion, though a coarser texture. When tender, it is eaten raw. It is also cooked with other vegetables or used as flavoring in soups and stews (Swamy and Gowda, 2006). Abd and Ali (2013) referred that fresh leeks are a good source of nitrates, flavonoids, polysaccharides and glucosinolates in addition to numerous organosulfur components contributing to their rich flavor. Adão $\boldsymbol{e t}$ al. (2011) published that leek is used, not only as food, but also as medicine. The bulbs have been reputedly used in the traditional Brazilian medicine for treating inflammatory symptoms. The crushed bulb is used to treat initial stages of cough, mucous secretion and sore throat. The fresh juice is taken orally as a stomachic and antispasmodic and is also reputed to possess digestive properties. Leeks are mainly grown in northern Europe and less frequently in India, the United States and Canada (Swamy and Gowda, 2006). Antioxidants are defined as compounds present at low concentration compared to the oxidisable substrate that can significantly delay or prevent oxidation of that substrate. Phenolic compounds are secondary metabolites are known to be responsible for the antioxidant activity of plants (Radovanović et al., 2015).

The leek is relatively unknown with respect to its content of total polyphenols and antioxidant activity in selected parts and cultivars of leek. The aim of the present study was to determine the content of polyphenols and antioxidant activity in selected varieties and parts of leek (Allium porrum L.) Our hypothesis is that different parts of the leek have different content of total polyphenols, values of antioxidant activity and we expects the positive correlation between antioxidant activity values and total polyphenols content in this experiment.

\section{MATERIAL AND METHODS}

\section{Plant material}

The samples of leek (Bavaria, Golem, Starozagorski kamuš, Albos) were collected in the phase of full ripeness from area of Zohor. All samples of plant material were grown under the same conditions. The samples of plant material were analyzed individually by selected methods, and were used in fresh material on analysis.

\section{The local climate conditions}

This study was performed in area of Zohor (Slovak Republic). It is situated on the western Slovakia (Zahorska lowland). Zohor belongs to warmer areas in Slovakia. Zahorska lowland is characterized by sandy soil and the cultivation of Allium plants such as onion, leek and garlic. The average annual rainfall is 600 $\mathrm{mm}$ and the average annual temperature is $9.5^{\circ} \mathrm{C}$. Agrochemical characteristic of soil from Zohor is shown in the Table 1. 
Table 1 Agrochemical characteristic of soil substrate in $\mathrm{mg} . \mathrm{kg}^{-1}$ from area Zohor

\begin{tabular}{|c|c|c|c|c|c|c|c|c|c|}
\hline \multirow{2}{*}{$\begin{array}{l}\text { Agrochemical } \\
\text { characteristic }\end{array}$} & $\begin{array}{l}\mathrm{pH} \\
\left(\mathrm{H}_{2} \mathrm{O}\right)\end{array}$ & $\begin{array}{l}\mathbf{p H} \\
(\mathbf{K C l})\end{array}$ & $\begin{array}{l}\text { Cox } \\
(\%)\end{array}$ & $\begin{array}{l}\text { Humus } \\
(\%)\end{array}$ & & & & & \\
\hline & 7.44 & 6.49 & 1.89 & 3.29 & & & & & \\
\hline \multirow{2}{*}{ Nutrients } & $\mathbf{K}$ & $\mathbf{C a}$ & Mg & $\mathbf{P}$ & & & & & \\
\hline & 279 & 7310.77 & 638.14 & 584.42 & & & & & \\
\hline Heavy metals & $\mathbf{Z n}$ & $\mathbf{C u}$ & Mn & $\mathrm{Fe}$ & $\mathrm{Cr}$ & $\mathbf{C d}$ & $\mathbf{P b}$ & Co & $\mathrm{Ni}$ \\
\hline Aqua regia & 87 & 11,24 & 376.42 & 8069.87 & 12,44 & 0.71 & 24,14 & 3.94 & 9.75 \\
\hline Limit value* & 100.0 & 60.0 & - & - & 70.0 & 0.4 & 70.0 & 15.0 & 40.0 \\
\hline $\begin{array}{l}\mathrm{NH}_{4} \mathrm{NO}_{3} \\
\left(\mathrm{c}=1 \mathrm{~mol} . \mathrm{dm}^{-3}\right)\end{array}$ & 0.13 & 0.08 & 0.12 & 0.06 & 0.02 & 0.05 & 0.11 & 0.05 & 0.15 \\
\hline Critical value $* *$ & 2.0 & 1.0 & - & - & - & 0.1 & 0.1 & - & 1.5 \\
\hline
\end{tabular}

**Critical value for $\mathrm{NH}_{4} \mathrm{NO}_{3}\left(\mathrm{c}=1\right.$ mol.dm $\left.{ }^{-3}\right)$ - Law no. $220 / 2004$

\section{Chemicals and extraction}

High-purity chemical reagents were used for all operations. Folin-Ciocalteu assay and gallic acid were purchased from Merck, Darmstadt, Germany. Sodium carbonate, methanol and 2,2-diphenyl-1-picrylhydrazyl radical (DPPH') were obtained from Sigma-Aldrich (St. Louis, Missouri, USA). The plants of leek were divided into three parts: white shaft (bulb), green shaft and leaves. The division of leek into the three monitored parts (white shaft, green shaft and leaves) is shown in Figure 1. The fresh white shaft (bulb), green shaft and leaves of leek were homogenized in the mixer (Kinematica AG, Luzern, Switzerland). Methanol extracts were prepared by adding $50 \mathrm{ml}$ of $80 \%$ methanol to $25 \mathrm{~g}$ milled sample and extracting in the shaker (Shaker GFL 3006, $125 \mathrm{rpm}$ ) for $12 \mathrm{~h}$ Samples were then filtered through filter paper $\left(130 \mathrm{~g} . \mathrm{m}^{-2}\right.$, Filtrak, Thermalbad Wiesenbad, Germany) and kept at $8{ }^{\circ} \mathrm{C}$ for further analysis. Each determination was carried out in six replications.

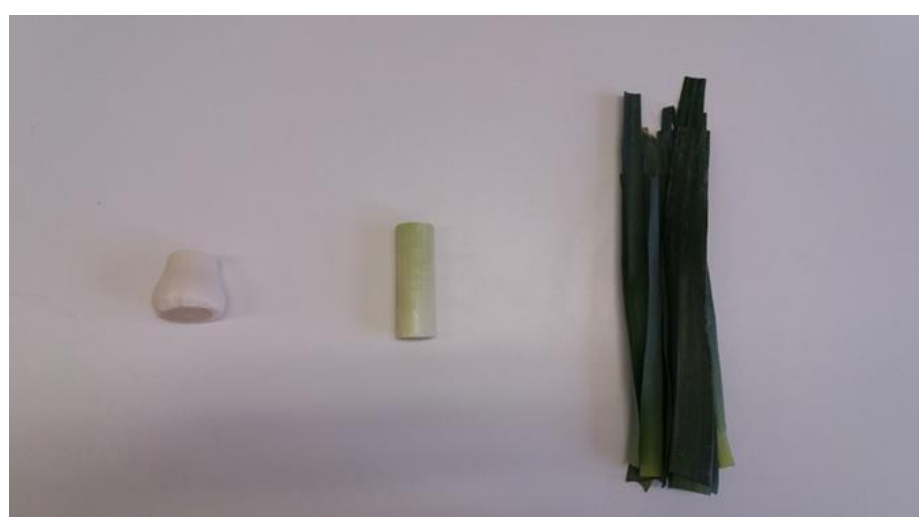

Figure 1 Three monitored parts of leeks - white shafts (bulb), green shafts and leaves

\section{Spectrophotometric determination of total polyphenols (TPC)}

Total polyphenols were determined by the method of Lachman et al. (2003) and expressed as milligrams of gallic acid equivalent per kilogram $\left(\mathrm{mg} \mathrm{GAE} . \mathrm{kg}^{-1}\right)$ dry weight (DW). Gallic acid is usually used as a standard unit for phenolics content determination because a wide spectrum of phenolic compounds. The total polyphenol content was estimated using Folin-Ciocalteau assay. The FolinCiocalteau (Merck) phenol reagent was added to a volumetric flask containing $100 \mathrm{ml}$ of extract of leek samples. The content was mixed and $5 \mathrm{ml}$ of a sodium carbonate solution by Merck $(20 \%)$ was added after $3 \mathrm{~min}$. The volume was adjusted to $50 \mathrm{ml}$ by adding of distilled water. After two hours the absorbance was measured at $765 \mathrm{~nm}$ (Spectrophotometer Shimadzu UV-1800; Shimadzu, Kyoto, Japan) of wavelength against blank. The concentration of polyphenols was calculated from a standard curve plotted with known concentration of gallic acid.

\section{Spectrophotometric determination of antioxidant activity (AOA)}

Antioxidant activity was measured by the Brand-Williams et al. (1995) methodusing a compound DPPH $^{*}$ (2.2-diphenyl-1-pikrylhydrazyl). 2.2-diphenyl-1pikrylhydrazyl (DPPH') was pipetted to cuvette $\left(3.9 \mathrm{~cm}^{3}\right)$ then the value of absorbance, which corresponded to the initial concentration of $\mathrm{DPPH}^{*}$ solution in time $\mathrm{A}_{0}$ was written. Then $0.1 \mathrm{~cm}^{3}$ of the followed solution was added and then the dependence $\mathrm{A}=\mathrm{f}(\mathrm{t})$ was immediately started to measure. The absorbance of 10 minutes at $515.6 \mathrm{~nm}$ in the spectrophotometer (Shimadzu UV - 1800 Shimadzu, Kyoto, Japan) was mixed and measured $\left(\mathrm{A}_{\mathrm{t}}\right)$. The percentage of inhibition reflects how antioxidant compound are able to remove $\mathrm{DPPH}^{-}$radical at the given time.
Computation:

$$
\% \text { inhibition } \mathrm{DPPH}^{*}=\frac{\mathrm{Ao}-\mathrm{At}}{\mathrm{Ao}} \times 100(\%)
$$

\section{Statistical analysis}

Results were statistically evaluated by the Analysis of Variance. All the assays were carried out in quadruplicates and results are expressed as mean \pm SD. The data were subjected to the F-test in the one-way analysis of variance (ANOVA) If the $p$-value of the F-test is less than 0.05 , there is a statistically significant difference between the at the $95 \%$ confidence level; the Multiple Range Tests will tell which means are significantly different from which others. The method currently being used to discriminate among the means of Fisher's least significant difference (LSD) procedure. Using statistical software Statgraphics Centurion XVI.I (Statpoint Technologies, The Plains, Virginia, USA) and a correlation analysis (Microsoft Excel, Washington, USA) was used.

\section{RESULTS AND DISCUSSION}

In this study the content of polyphenols and antioxidant activity (\% inhibition) in selected cultivars (Bavaria, Golem, Starozagorski kamuš, Albos) and parts (white shaft, green shaft and leaves) of leek were tested and evaluated. The results of antioxidant activity value and the content of total polyphenols in selected samples of leek are summarized in Table 2 and Table 3.

The content of total polyphenols in selected samples cultivars of leek ranges from $504.22 \pm 48.28 \mathrm{mg} \mathrm{GAE} . \mathrm{kg}^{-1} \mathrm{DW}$ (white shaft) of cultivar Bavaria to $4767.71 \pm$ 80.55 mg GAE.kg-1 DW (leaves) of cultivar Golem.

Table 2 The average contents of total polyphenols (mg GAE.kg-1 DW) in selected cultivars and parts of leek

\begin{tabular}{lll}
\hline Variety & Part of plants & $\begin{array}{l}\text { TPC } \\
\left(\mathbf{m g ~ G A E . k g ^ { - 1 }} \pm \mathbf{S D}\right) \mathbf{D W}\end{array}$ \\
\hline \multirow{3}{*}{ Bavaria } & White shaft & $504,22 \pm 48,28^{\mathrm{A}, \mathrm{a}}$ \\
& Green shaft & $776,58 \pm 76,78^{\mathrm{B}, \mathrm{b}}$ \\
& Leaves & $3686,81 \pm 89,15^{\mathrm{C}, \mathrm{h}}$ \\
\hline \multirow{3}{*}{ Golem } & White shaft & $847,45 \pm 49,65^{\mathrm{A}, \mathrm{b}, \mathrm{c}}$ \\
& Green shaft & $1011,49 \pm 26,50^{\mathrm{B}, \mathrm{d}}$ \\
& Leaves & $4767,71 \pm 80,55^{\mathrm{C}, \mathrm{j}}$ \\
\hline \multirow{3}{*}{ Starozagorski kamuš } & White shaft & $883,92 \pm 30,25^{\mathrm{A}, \mathrm{c}}$ \\
& Green shaft & $973,95 \pm 73,80^{\mathrm{A}, \mathrm{d}}$ \\
& Leaves & $3371,16 \pm 50,42^{\mathrm{B}, \mathrm{g}}$ \\
\hline \multirow{3}{*}{ Albos } & White shaft & $1117,19 \pm 42,87^{\mathrm{A}, \mathrm{e}}$ \\
& Green shaft & $1224,09 \pm 71,81^{\mathrm{B}, \mathrm{f}}$ \\
& Leaves & $4232,37 \pm 34,10^{\mathrm{C}, \mathrm{i}}$ \\
\hline
\end{tabular}

Note: ${ }^{A-C}$ values with different letters mean significant differences $(p<0.05)$ among selected parts of leek; ${ }^{\mathrm{a}-\mathrm{j}}$ values with different letters mean significan differences $(p<0.05)$ among selected parts and cultivars of leek, contents of total polyphenols are expressed as arithmetic mean

Based on the measured content of total polyphenols in selected parts of leek can be in the ensuing order: leaves > green shaft > white shaft. In cultivar Golem (leaves) average content of total polyphenols is 9.46-times higher than in cultivar Bavaria (white shaft). 
Table 3 The average values of antioxidant activity (\% inhibition) in selected cultivars and parts of leek

\begin{tabular}{lll}
\hline Variety & Part of plants & $\begin{array}{l}\text { AOA } \\
(\% \text { inhibition } \pm \text { SD })\end{array}$ \\
\hline \multirow{3}{*}{ Bavaria } & White shaft & $12,53 \pm 2,24^{\mathrm{A}, \mathrm{d}}$ \\
& Green shaft & $9,88 \pm 2,17^{\mathrm{A}, \mathrm{b}, \mathrm{c}}$ \\
& Leaves & $42,36 \pm 2,99^{\mathrm{B}, \mathrm{f}}$ \\
\hline \multirow{3}{*}{ Golem } & White shaft & $9,63 \pm 1,84^{\mathrm{A}, \mathrm{b}, \mathrm{c}}$ \\
& Green shaft & $8,64 \pm 0,40^{\mathrm{A}, \mathrm{b}}$ \\
& Leaves & $47,40 \pm 0,49^{\mathrm{B}, \mathrm{g}}$ \\
\hline \multirow{3}{*}{ Starozagorski kamuš } & White shaft & $4,30 \pm 1,02^{\mathrm{A}, \mathrm{a}}$ \\
& Green shaft & $5,41 \pm 1,13^{\mathrm{A}, \mathrm{a}}$ \\
& Leaves & $40,84 \pm 1,38^{\mathrm{B}, \mathrm{f}}$ \\
\hline \multirow{3}{*}{ Albos } & White shaft & $11,10 \pm 0,94^{\mathrm{A}, \mathrm{c}, \mathrm{d}}$ \\
& Green shaft & $10,02 \pm 0,40^{\mathrm{A}, \mathrm{b}, \mathrm{c}}$ \\
\hline
\end{tabular}

Note: ${ }^{\mathrm{A}-\mathrm{B}}$ values with different letters mean significant differences $(p<0.05)$ among selected parts of leek; ${ }^{\text {a-h }}$ values with different letters mean significant differences $(p<0.05)$ among selected parts and cultivars of leek, values of antioxidant activity are expressed as arithmetic mean

Koca and Tasci (2015) published that the content of total polyphenols was recorded in selected cultivars of leek in the interval from 2130 mg.kg-1 DW to $4780 \mathrm{mg} \cdot \mathrm{kg}^{-1} \mathrm{DW}$. In comparison to our determined values of polyphenols their results were in similar interval. Our results are lower compared to Bernaert et al. (2012), who has published the content of total polyphenols in the range from $5310 \mathrm{mg} \cdot \mathrm{kg}^{-1} \mathrm{DW}$ of cultivar Poribleu to $9070 \mathrm{mg} \cdot \mathrm{kg}^{-1} \mathrm{DW}$ of cultivar Farinto. Our results are in correspondence with the results of Tiveron $\boldsymbol{e t}$ al. (2012) who indicated the content of polyphenols in leek $1200 \mathrm{mg} \cdot \mathrm{kg}^{-1} \mathrm{DW}$ and Turkmen et al. (2005) who indicated the content of polyphenols in leek $3800 \mathrm{mg} \cdot \mathrm{kg}^{-1} \mathrm{DW}$. Statistically significant highest content of total polyphenols $(p<0.05)$ was recorded in leaves in cultivar of Golem (4767.71 mg GAE. $\left.\mathrm{kg}^{-1} \mathrm{DW}\right)$. Statistically significant the lowest content of total polyphenols $(p<0.05)$ was recorded in white shaft in cultivar of Bavaria (504.22 mg GAE.kg ${ }^{-1} \mathrm{DW}$ ).

Another indicator that has been evaluated and compared was the antioxidant activity of selected cultivars of leek (Bavaria, Golem, Starozagorski kamuš, Albos). The values of antioxidant activity were in interval from $4.30 \pm 1.02 \%$ inhibition (white shaft) of cultivar Starozagorski kamuš to $47.40 \pm 0.49 \%$ inhibition (leaves) of cultivar Golem. Based on the measured values of antioxidant activity in selected parts of leek (white shaft, green shaft and leaves) can be in the ensuing order: leaves > white shaft, green shaft. In terms of antioxidant activity it was not a statistically significant difference between the white shaft and green shaft of leek. Vishwakarma et al. (2014) determines in his study higher values, in comparison with our results. Their values were in interval from $76.22 \%$ inhibition to $91 \%$ inhibition. Kavalcová et al. (2014) reported that the value of antioxidant activity was recorded in leek in the interval from $8.55 \%$ inhibition to $12.92 \%$ inhibition. In comparison to our determined values of antioxidant their results were in similar interval. Our results are in correspondence with the results of Abdel-Salam et al. (2014) who indicated the value of antioxidant activity in leek $14 \%$ inhibition.

In this study we have found also positive relation between the content of total polyphenols and antioxidant activity in white shaft, green shaft and leaves of leek $(r=0.910, r=0.938, r=930)$. There are very few studies that deal with the relation between content of total polyphenols and antioxidant activity in leek.

Results are shown in Figure 2, Figure 3 and Figure 4. These results are in good accordance with Beretta et al. (2017), who reported a positive correlation between total antioxidant activity and total phenolic content in selected species of Allium genus $(\mathrm{R}=0.91)$. Lachowicz et al. (2017) also observed a positive relation between antioxidant activity and the content of polyphenolic compounds.

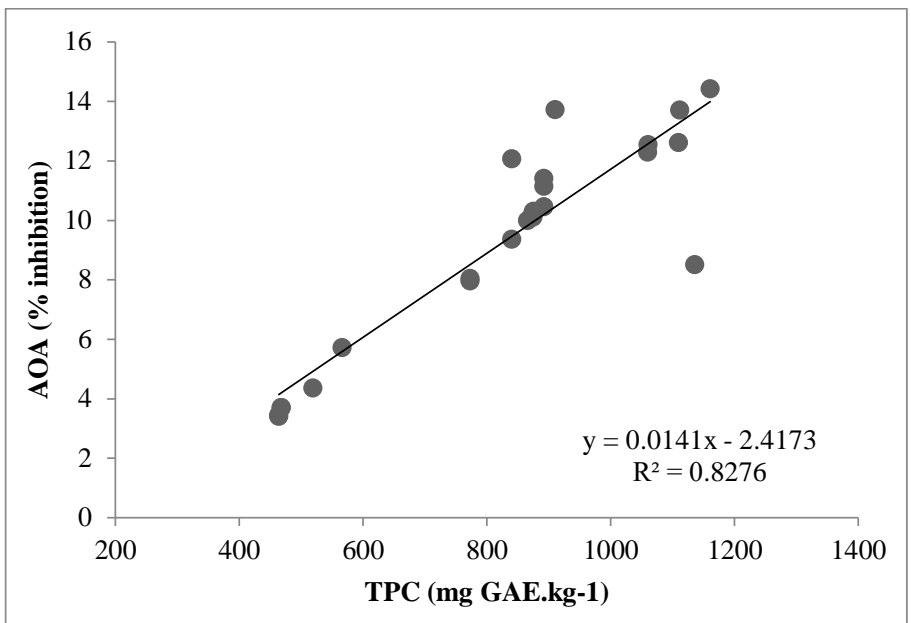

Figure 2 Relation between antioxidant activity (AOA) and total polyphenols content (TPC) in white shafts (bulbs) of monitored leeks

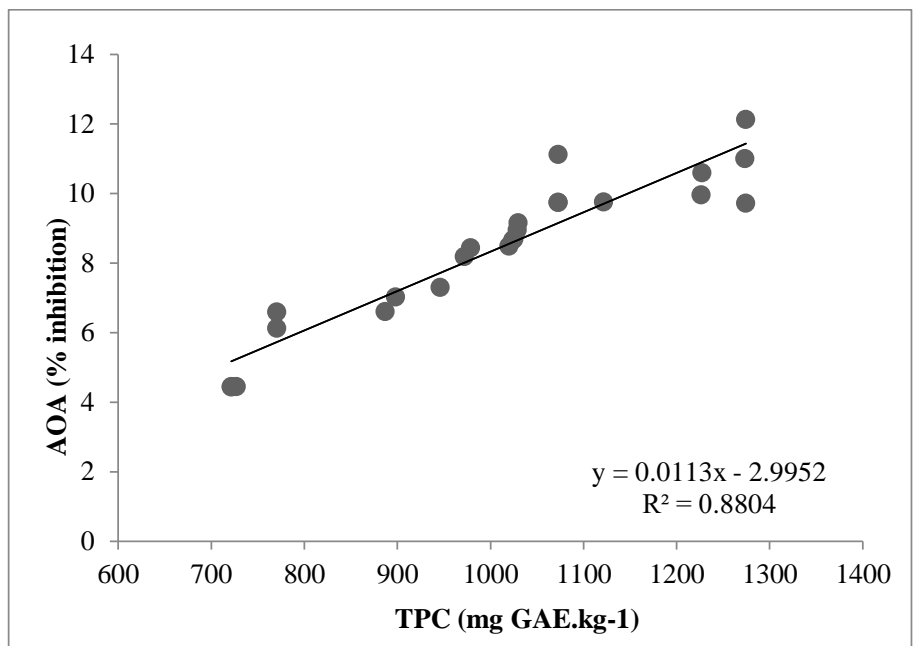

Figure 3 Relation between antioxidant activity (AOA) and total polyphenols content (TPC) in green shafts of monitored leeks

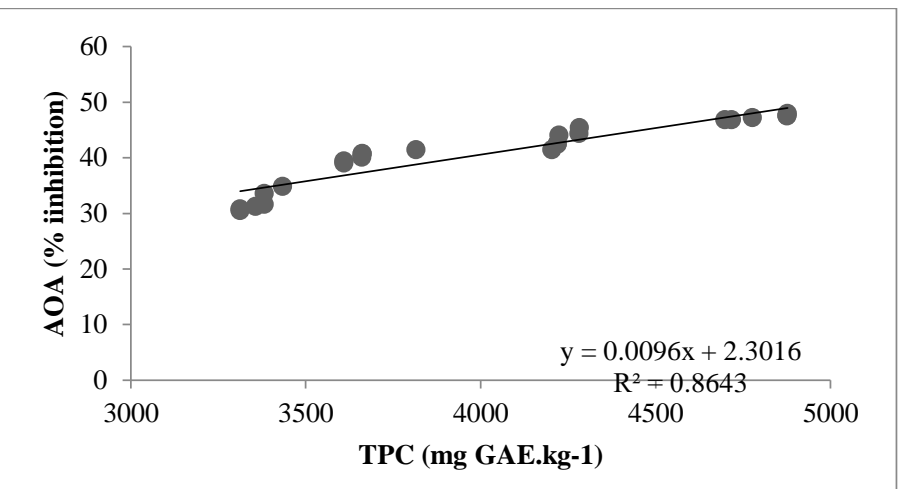

Figure 4 Relation between antioxidant activity (AOA) and total polyphenols content (TPC) in leaves of monitored leeks

\section{CONCLUSION}

To date, recorded very few publications that are associated with bioactive compounds of leek (Allium porrum L.). The present paper was focused on the content of total polyphenols and antioxidant activity in selected cultivars and parts of leek. It was shown that the content of polyphenols and antioxidant activity of leek is parts of plant and variety-dependent in this study. The results suggest that leaves of leek showed higher content of polyphenols and antioxidant activity than the white shaft and green shaft of leek in this study. It is a pity that the leaves are rarely used in food industry. It is also important to note that the results of the present study require further experiments such as determination of phenolic acids, vitamin $\mathrm{C}$ and macroelements content in leek.

Acknowledgments: This work was supported by scientific grant VEGA 1/0139/17, VEGA 1/0114/18, KEGA 011SPU-4/2017. 


\section{REFERENCES}

Act No. 220/2004 Coll. Of Laws of Slovak Republic. On the conservation and use of agricul- tural land, amending the Act No. 245/2003 Coll. on integrated pollution prevention and control, amending and supplementing of certain acts, as amended.

ABD, F. A. E. R. A., ALI, R. F. M. 2013. Proximate compositions, phytochemical constituents, antioxidant activities and phenolic contents of seed and leaves extracts of Egyptian leek (Allium ampeloprasum var. kurrat). European Journal of Chemistry, 4(3), 185-190. https://doi.org/10.5155/eurjchem.4.3.185-190.711.

ABDEL-SALAM, A. F., SHAHENDA, M. E., JEHAN, B. A. 2014 Antimicrobial and antioxidant activities of red onion, garlic and leek in sausage. African Journal of Microbiology Research,8(27), 2574-2582. https://doi.org/10.5897/AJMR2014.6755.

ADÃO, C. R., DA SILVA, B. P., PARENTE, J. P. 2011. A new steroidal saponin with antiinflammatory and antiulcerogenic properties from the bulbs of Allium $\begin{array}{llll}\text { ampeloprasum } & \text { var. } & \text { porrum. Fitoterapia, } 82 \quad \text { (8), } & 1175-1180\end{array}$ https://doi.org/10.1016/j.fitote.2011.08.003.

BARBA, F. J., MARIUTTI, L. R., BRAGAGNOLO, N., MERCADANTE, A. Z., BARBOSA-CÁNOVAS, G. V., ORLIEN, V. 2017. Bioaccessibility of bioactive compounds from fruits and vegetables after thermal and nontherma processing. Trends in Food Science \& Technology, 67, 195-206. https://doi.org/10.1016/j.tifs.2017.07.006.

BERETTA, H. V., BANNOUD, F., INSANI, M., BERLI, F., HIRSCHEGGER, P., GALMARINI, C. R., CAVAGNARO, P. F. 2017. Relationships between bioactive compound content and the antiplatelet and antioxidant activities of six allium vegetable species. Food technology and biotechnology, 55(2), 266 https://doi.org/10.17113/ftb.55.02.17.4722.

BERNAERT, N., DE CLERCQ, H., VAN BOCKSTAELE, E., DE LOOSE, M. VAN DROOGENBROECK, B. 2013. Antioxidant changes during postharvest processing and storage of leek (Allium ampeloprasum var. porrum). Postharvest $\begin{array}{lll}\text { biology } \quad \text { and } & \text { technology, 86, }\end{array}$ https://doi.org/10.1016/j.postharvbio.2013.06.010.

BRAND-WILLIAMS, W., CUVELIER, M. E., BERSET, C. L. W. T. 1995. Use of a free radical method to evaluate antioxidant activity. LWT-Food science and Technology, 28(1), 25-30. http://dx.doi.org/10.1016/S0023-6438(95)80008-5.

CONNELL, P. M., FINKELSTEIN, S. R., SCOTT, M. L., VALLEN, B. 2018. Negative associations of frozen compared with fresh vegetables. Appetite, 127 296-302. https://doi.org/10.1016/j.appet.2018.05.134.

GARCÍA-HERRERA, P., MORALES, P., FERNÁNDEZ-RUIZ, V., SÁNCHEZ MATA, M. C., CÁMARA, M., CARVALHO, A. M., FERREIRA, I.C.F.R., PARDO-DE-SANTAYANA, M., MOLINA, M., TARDÍO, J. 2014. Nutrients, phytochemicals and antioxidant activity in wild populations of Allium ampeloprasum L., a valuable underutilized vegetable. Food research international, 62, 272-279. https://doi.org/10.1016/j.foodres.2014.03.004.

KAVALCOVÁ, P., BYSTRICKÁ, J., TOMÁS̆, J., KAROVIČOVÁ, J., KUCHTOVÁ, V. 2014. Evaluation and comparison of the content of total polyphenols and antioxidant activity in onion, garlic and leek. Potravinarstvo Slovak Journal of Food Sciences, 8(1), 272-276. https://doi.org/10,5219/394.

KOCA, I., TASCI, B. 2015. Mineral composition of leek. In VII International Symposium on Edible Alliaceae 1143 (pp. 147-152). https://doi.org/10.17660/ActaHortic.2016.1143.21.

KRATCHANOVA, M., NIKOLOVA, M., PAVLOVA, E., YANAKIEVA, I., KUSSOVSKI, V. 2010. Composition and properties of biologically active pectic polysaccharides from leek (Allium porrum). Journal of the Science of Food and Agriculture, 90(12), 2046-2051. https://doi.org/10.1002/jsfa.4050.

LACHMAN, J., PRONEK, D., HEJTMANKOVA, A., DUDJAK, J., PIVEC, V., FAITOVÁ, K. 2003. Total polyphenol and main flavonoid antioxidants in different onion (Allium cepa L.) varieties. Horticultural science, 30(4), 142-147. https://doi.org/10.17221/3876-HORTSCI.

LACHOWICZ, S., OSZMIAŃSKI, J., PLUTA, S. 2017. The composition of bioactive compounds and antioxidant activity of Saskatoon berry (Amelanchier alnifolia Nutt.) genotypes grown in central Poland. Food Chemistry, 235, 234 243. https://doi.org/10.1016/i.foodchem.2017.05.050.

PEREZ-CORNAGO, A., TRAVIS, R. C., APPLEBY, P. N., TSILIDIS, K. K., TJØNNELAND, A., OLSEN, A., OVERVAD, K., KATZKE, V., KUHN, T., TRICHOPOULOU, A., PEPPA, E., KRITIKOU, M., SIERI, S., PALLI, D., SACERDOTE, C., TUMINO, R., BUENO-DE-MESQUITA, H.B., AGUDO, A., LARRA NAGA, N., MOLINA-PORTILLO, E., ARDANAZ, E., CHIRLAQUE, M.-D., LASHERAS, C., STATTIN, P., WENNBERG, M., DRAKE, I., MALM, J., SCHMIDT, J. A., KHAW, K.-T., GUNTER, M., FREISLING, H., HUYBRECHTS, I., AUNE, D., CROSS, A. J., RIBOLI, E., KEY, T.J. 2017. Fruit and vegetable intake and prostate cancer risk in the European Prospective Investigation into Cancer and Nutrition (EPIC). International journal of cancer, 141(2), 287-297. https://doi.org/10.1002/ijc.30741.

RADOVANOVIĆ, B., MLADENOVIĆ, J., RADOVANOVIĆ, A., PAVLOVIĆ, R., NIKOLIĆ, V. 2015. Phenolic composition, antioxidant, antimicrobial and cytotoxic activites of allium porrum L.(Serbia) extracts. Journal of Food and Nutrition Research, 3(9), 564-569. https://doi.org/10.12691/jfnr-3-9-1.
SWAMY, K. R. M., GOWDA, R. V. 2006. Leek and shallot. In Handbook of Herbs and Spices, 3, 365-389. https://doi.org/10.1533/9781845691717.3.365.

TIVERON, A. P., MELO, P. S., BERGAMASCHI, K. B., VIEIRA, T. M., REGITANO-D'ARCE, M. A., ALENCAR, S. M. 2012. Antioxidant activity of Brazilian vegetables and its relation with phenolic composition. International journal of molecular sciences, 13(7), 8943-8957. https://doi.org/10,3390/ijms13078943.

TURKMEN, N., SARI, F., VELIOGLU, Y. S. 2005. The effect of cooking methods on total phenolics and antioxidant activity of selected green vegetables. Food chemistry, 93(4), 713-718. https://doi.org/10.1016/j.foodchem.2004.12.038.

VISHWAKARMA, S., CHANDAN, K., JEBA, R. C., KHUSHBU, S. 2014. Comparative study of qualitative phytochemical screening and antioxidant activity of Mentha arvensis, Elettaria cardamomum and Allium porrum. Ind 